\title{
PENGARUH MODEL PROBLEM BASED LEARNING UNTUK MENINGKATKAN PRESTASI BELAJAR SISWA PADA MATA PELAJARAN MATEMATIKA SISWA KELAS V SDN 5 BANYUMULEK KABUPATEN LOMBOK BARAT
}

\author{
M. Zainal Mustamiin \\ Program Studi Bimbingan dan Konseling, FIPP UNDIKMA \\ Email: mzainalmustamiin@yahoo.com
}

\begin{abstract}
Abstrak: Tujuan yang ingin dicapai didalam penelitian ini adalah untuk mengetahui meningkatkan prestasi belajar siswa kelas V SD Negeri 5 Banyumulek dengan menerapkan model Problem Based-Learning. Jenis penelitian ini adalah penelitian tindakan kelas yang dilakukan dalam dua siklus yang terdiri dari tahap perencanaan, observasi, evaluasi dan refleksi. Data aktivitas guru dan siswa diambil menggunakan lembar observasi, sedangkan data prestasi belajar siswa diperoleh melalui tes yang diberikan pada tiap akhir siklus. Dari hasil observasi terhadap aktivitas siswa dan guru pada siklus I dan II menujukkan bahwa, persentasi ketercapaian siswa pada siklus I adalah 53\%. Pada siklus II persentasi ketercapaian siswa adalah $80 \%$, sedangkan dari hasil observasi aktivitas terhadap guru pada siklus I dan siklus II menujukkan bahwa persentasi ketercapaian guru pada siklus I adalah $80 \%$, dan pada siklus II persentasi ketercapaian guru adalah $100 \%$, dan hasil evaluasi siswa pada siklus I diperoleh persentasi ketuntasan belajar siswa sebesar $71.42 \%$, sedangkan pada siklus II diperoleh persentasi ketuntasan belajar siswa sebesar $89.29 \%$. Sehingga terjadi peningkatan prestasi belajar siswa dari siklus I ke siklus II sebesar $17.78 \%$, ini menandakan bahwa dengan penerapan metode Problem Based-Learning dapat meningkatkan aktivitas dan prestasi belajar matematika siswa pada materi pokok pengerjaan hitung bilangan pecahan di kelas V SD Negeri 5 Banyumulek tahun pelajaran 2019/2020.
\end{abstract}

Kata kunci: Prestasi Belajar, Problem Based Learning

\section{PENDAHULUAN}

Keterampilan pemecahan masalah menjadi hal yang sangat penting dalam pelaksanaan pembelajaran di kelas. Keterampilan memecahkan masalah perlu dijadikan pedoman di dalam sebuah pembelajaran dengan kata lain bahwa proses pembelajaran tidak hanya mampu memberikan keterampilan kepada peserta didik merespon suatu pertanyaan dari guru dengan satu jawaban saja. Akan tetapi, peserta didik mampu mengkonstruksi pertanyaan dari guru dengan memadukan jawaban sesuai dengan pengalaman dan pemahaman yang dimiliki peserta didik. Hal ini akan menyebabkan pelaksanaan proses pembelajaran menjadi lebih aktif dan responsif.

Pemecahan masalah merupakan bagian dari pembelajaran matematika yang sangat penting Karena dalam proses pembelajaran matematika banyak guru yang mengeluhkan rendahnya kemampuan peserta didikdalam menerapkan konsep matematika secara sederhana. Hal ini terlihat dari banyaknya kesalahan peserta didikdalam memahami konsep matematika itu sendiri, sehingga mengakibatkan kesalahan-kesalahan dalam mengerjakan soal yang mengakibatkan rendahnya prestasi belajar peserta didikbaik dalam ulangan harian, ulangan semester, maupun ujian akhir sekolah .

Hasil pengamatan yang dilakukan ditemukan beberapa masalah yang terhadap pelaksanaan proses pembelajaran matematika serta perolehan hasil belajar peserta didik yaitu pembelajaran matematika pada kelas $\mathrm{V}$ semester II masih menggunakan pembelajaran konvensional, dimana proses pembelajaran masih didominasi oleh guru (teacher centered) sehingga menyebabkan aktivitas peserta didik dalam pembelajaran dikelas menjadi pasif dan kurang aktif. Oleh sebab itu partisipasi peserta didik untuk menentukan prosedur pemecahan suatu masalah masih kurang karena minimnya model pembelajaran yang digunakan dan 
pada akhirnya menyebabkan rendahnya prestasi belajar siswa.

Upaya yang dilakukan untuk mengatasi masalah tersebut adalah dengan cara menerapkan model pembelajaran Problem-Based Learning. Model pembelajaran ini menyebabkan peserta didik dilatih untuk berfikir mandiri untuk memecahkan berbagai masalah terutama yang terkait dengan aplikasi materi pelajaran didalam kehidupan nyata (Gintings, 2009:111).

Pembelajaran dengan model Problem Based-Learning ini akan memberikan kesempatan kepada peserta didikuntuk menggunakan kemampuannya untuk berpikir dan memperoleh suatu konsep atau prinsip dalam memecahkan suatu masalah. Dengan demikian, peserta didikakan terbiasa berfikir secara sistematis dan bertahap dari hal yang mudah ke hal yang sukar, karena model Problem Based-Learning ini, peserta didiktidak hanya mendapatkan materi yang telah jadi, namun merumuskan suatu masalah agar dapat dipecahkan sehingga apa yang didapat oleh peserta didikdari pembelajaran tersebut dapat melekat dalam ingatan mereka lebih lama.

Berdasarkan uraian diatas, maka dipandang merasa perlu melakukan penelitian tindakan kelas dengan judul "Meningkatkan Prestasi Belajar Dengan Menerapkan Model Problem Based Learning Pada Mata Pelajaran Matematika Peserta didik kelas V SD Negeri 5 Banyumulek Kabupaten Lombok Barat Tahun Pelajaran 2019/2020.

\section{KAJIAN PUSTAKA}

\section{Hakekat Matematika}

Istilah Matematika berasal dari bahasa yunani yaitu "Mathematikos" secara ilmu pasti, mathesis yaitu berarti ajaran pengetahuan abstrak dan deduktif, dimana kesimpulan tidak ditarik berdasarkan pengalaman keindraan, tetapi atas kesimpulan yang ditarik dari kaedah-kaedah melalui deduksi. Ditijau dari aspek kompetensi yang ingin dicapai, mata pelajaran matamatika menekankan penguasaan konsep dan alogaritma serta keterampilan memecahkan masalah.

Hudoyo ( Irzani, 2010: 4) menyatakan bahwa Matematika adalah ilmu yang berkaitan dengan bilanganbilangan. Pengertian matematika yang tercantum di dalam pengembangan kurikulum matematika dan pembelajaran matematika (2005) adalah sebagai berikut: "Matematika adalah suatu alat untuk mengembangkan cara berfikir.

Dengan demikian dapat dikatakan bahwa matematika merupakan ilmu pengetahuan yang mempelajari struktur yang abstrak dan pola hubungan yang ada di dalamnya. Ini berarti bahwa belajar matematika pada hakekatnya adalah belajar konsep, struktur konsep dan mencari hubungan antara konsep dan strukturnya.

\section{Pembelajaran berbasis masalah (Problem Based-Learning)}

Karakteristik pembelajaran berbasis masalah

Pembelajaran berbasis masalah merupakan model pembelajaran yang titik tolaknya adalah adanya permasalahan yang disepakati oleh guru dan peserta didik. Pepper (2009:128) menyatakan bahwa "Problem Based Learning (PBL) is a recognised teaching and learning strategy used to engaged students in deep rather than surface lerning". Artinya bahwa pembelajaran berbasis masalah adalah strategi pembelajaran yang melibatkan peserta didik dalam pemahaman yang dalam dibandingkan dengan pembelajaran konvensional.

Dari beberapa pendapat di atas, dapat disimpulkan bahwa ada satu karakteristik khusus dari pembelajaran berbasis masalah. Masalah menjadi landasan utama proses pembelajaran. Masalah akan menuntun peserta didik dalam proses pembelajaran, menjadikan peserta didik menjadi tertantang dalam menyelesaikan masalah, dan masalah 
yang dihadapi diperoleh dari berbagai lingkup seperti lingkungan sekitar.

Esensinya pembelajaran berbasis masalah adalah memberikan berbagai situasi bermasalah yang otentik dan bermakna kepada peserta didik yang dapat berfungsi sebagai batu loncatan untuk penyelidikan (Tan, 2009: 7). Pembelajaran berbasis masalah menjadikan peserta didik menjadi pembelajar yang mandiri artinya bahwa ada kebebasan kepada peserta didik untuk mencari dan menyelidiki permasalahan yang dihadapi kemudian menemukan solusinya dengan acuan dan pedoman yang telah diberikan guru.

\section{Prestasi Belajar}

Menurut Poerwadarmita, prestasi adalah hasil yang telah dicapai (dikerjakan dan dilakukan). Sedangkan menurut Mas'ud Khasan Abdul Qobar, prestasi adalah apa yang telah didapat, diciptakan, hasil pekerjaan, hasil yang menyenangkan hati yang diperoleh dengan jalan keuletan kerja (Djamarah, 1994 : 20).

Menurut Sadirman, mengemukakan suatu rumusan bahwa, belajar adalah sebagai rangkaian kegiatan jiwa dan raga, psikofisik menuju ke perkembangan pribadi manusia seutuhnya yang menyangkut unsur cipta, rasa dan karsa, ranah koginif, afektif dan psikomotorik (Djamarah, 1994 : 21).

Berdasarkan uraian pendapat diatas, bahwa prestasi belajar adalah hasil yang diperoleh berupa kesan-kesan yang mengakibatkan perubahan dalam diri individu sebagai hasil aktivitas dalam belajar, yang dilambangkan dengan tes hasil evaluasi hasil belajar.

\section{METODE PENELITIAN}

Penelitian ini dilaksanakan pada materi pokok pengerjaan hitung bilangan pecahan dengan alokasi waktu belajar yaitu tiga jam pelajaran. Penelitiian ini dilaksanakan dalam dua siklus, setiap siklus terdiri dari satu kali pertemuan dan di setiap akhir siklus dilakukan evaluasi. Adapun indikator yang akan dicapai pada setiap siklus dapat dilihat pada tabel dibawah ini.

\section{Instrumen Pengumpulan Data}

Instrumen yang digunakan untuk mengumpulkan data dalam penelitian ini antara lain:

1. Lembar soal

Lembar soal bertujuan untuk mengetahui hasil belajar siswa. Jenis soal tes yang digunakan adalah dalam bentuk essay, ini dibuat guna mengetahui sejauh mana tingkat kemampuan peserta didik dalam memahami materi yang telah diberikan. Teknik pensekoran untuk mengetahui hasil belajar peserta didik menggunakan rumus sebagai berikut:

a) Untuk menganalisis prestasi peserta didik menggunakan rumus dengan cara:

$$
\begin{aligned}
& \text { NA }=\frac{S A}{S m i} \times 100 \% \\
& \text { Keterangan }: \\
& \text { NA }=\text { Nilai Akhir } \\
& \text { SA }=\text { Skor Aktual } \\
& \text { Smi }=\text { Skor Maksimal ideal }
\end{aligned}
$$

b) Untuk mengetahui data hasil tes belajar peserta didikakan dianalisis dengan rumus :

$$
\mathrm{KK}=\frac{P}{N} \mathrm{X} 100 \%
$$

Keterangan:

$\mathrm{KK}=$ Ketuntasan Klasikal

$\mathrm{P}=$ Jumlah peserta

didikyang memperoleh nilai $\geq 65$

$\mathrm{N}=$ Jumlah peserta didikyang mengikuti tes.

\section{Tekhnik Analisa Data}

1. Data Aktivitas Siswa

Data aktivitas peserta didikdiambil menggunakan lembar observasi dengan memberikan check lisk pada setiap indikator/deskriptor. Setiap indikator prilaku peserta didik pada penelitian ini penskorannya mengikuti aturan sebagai berikut. 
a. Skor 4 jika $\geq 75 \%$ peserta didikmelakukan deskriptor yang diamati

b. Skor 3 jika $\geq 50-74 \%$ peserta didik melakukan deskriptor yang diamati

c. Skor 2 jika $\geq 25-49 \%$ peserta didik melakukan deskriptor yang diamti

d. Skor 1 jika $<25 \%$ peserta didik melakukan deskriptor yang diamati

Untuk menganalisis aktivitas peserta didik menggunakn rumus dengan cara:

$$
\mathrm{NA}=\frac{S A}{S m i} \times 100 \%
$$

Keterangan :

$\mathrm{NA}=$ Nilai Akhir

$\mathrm{SA}=$ Skor Aktual

Smi $=$ Skor Maksimal ideal
Kategori penilaian aktivitas peserta didik menggunakan rumus yaitu :

a. $\mathrm{Mi}=\frac{1}{2} \mathrm{X}$ (Skor Maksimal + Skor Minimal)

$$
\mathrm{MI}=\frac{1}{2} \mathrm{X}(100+0)=50
$$

b. $\quad$ SDi $=\frac{1}{6} X$ ( Skor Maksimal - Skor Minimal )

$$
\mathrm{SDi}=\frac{1}{6} \mathrm{X}(100-0)=16,66
$$

bulatan menjadi 17

Berdasarkan skor standar maka kriteria untuk menentukan aktivitas peserta didik dijabarkan pada tabel berikut (Nurkencana 1990 : 100).

Tabel 4. Pedoman kriteria aktivitas siswa

\begin{tabular}{|c|c|c|}
\hline Interval & Skor & Kriteria \\
\hline $\mathrm{A} \geq \mathrm{Mi}+2 \mathrm{Sdi}$ & $84-100$ & Sangat Aktif \\
\hline $\mathrm{Mi}+1 \mathrm{Sdi} \mathrm{s} / \mathrm{d}<\mathrm{MI}+2 \mathrm{Sdi}$ & $67-83$ & Aktif \\
\hline $\mathrm{Mi}-1 \mathrm{SDi} \mathrm{s} / \mathrm{d}<\mathrm{Mi}+1 \mathrm{Sdi}$ & $33-66$ & Cukup Aktif \\
\hline $\mathrm{Mi}-\mathrm{Sdi}$ s/d $<\mathrm{Mi}-1 \mathrm{Sdi}$ & $16-32$ & Kurang Aktif \\
\hline$<\mathrm{Mi}-2 \mathrm{Sdi}$ & $<15$ & Tidak Aktif \\
\hline
\end{tabular}

2. Data Aktivitas Guru

Penilaian aktivitas guru dilakukan melalui observer lansung (directed observation) dimana seorang guru yang sedang mengajar diobservasi langsung oleh observer (pengamatan) dan observer berada bersam-sama guru dan peserta didik didalam kelas. Setiap indikator prilaku guru pada penelitian ini pensekorannya mengikuti aturan sebagai berikut :

a. Skor 4 diberikan jika 3 deskriptor yang diamati nampak

b. Skor 3 diberikan jika 2 deskriptor yang diamati nampak

c. Skor 2 diberikan jika 1 deskriptor yang diamati nampak d. Skor 1 diberikan jika tidak ada deskriptor yang diamati nampak.

Pedoman konversi atau kriteria penilaian aktivitas guru hampir sama dengan kriteria penilaian aktivitas siswa, hanya berbeda pada kata gorinya, sebagai berikut.

Tabel 5. Pedoman kriteria aktivitas guru

\begin{tabular}{|c|c|}
\hline Rentang Nilai & Kategori \\
\hline $81-100$ & Sangat baik \\
\hline $61-80$ & Baik \\
\hline $41-60$ & Cukup baik \\
\hline $21-40$ & Kurang baik \\
\hline $0-20$ & Tidak baik \\
\hline
\end{tabular}

3. Data pretasi belajar siswa 
a. Untuk menganalisis prestasi peserta didik menggunakan rumus dengan cara

$$
\mathrm{NA}=\frac{S A}{S m i} \times 100 \%
$$

Keterangan :

NA $=$ Nilai Akhir

SA $=$ Skor Aktual

Smi $=$ Skor Maksimal ideal

b. Untuk mengetahui data hasil tes belajar peserta didikakan dianalisis dengan rumus :

$$
\mathrm{KK}=\frac{P}{N} \mathrm{X} 100 \%
$$

Keterangan:

$$
\begin{aligned}
& \mathrm{KK} \quad=\text { Ketuntasan Klasikal } \\
& \mathrm{P} \quad=\text { Jumlah peserta didikyang } \\
& \text { memperoleh nilai } \geq 65 \\
& \mathrm{~N} \quad=\text { Jumlah peserta didikyang } \\
& \text { mengikuti tes. }
\end{aligned}
$$

Prestasi belajar peserta didik dikatakan meningkat apabila terdapat peningkatan dari rata-rata nilai sebelumnya dan minimal rata-rata nilai mencapai 65 pada siklus akhir (Nurkancana 1983 : 104).

\section{HASIL DAN PEMBAHASAN}

\section{Deskripsi Hasil Analisis Berdasarkan Siklus}

Siklus I

\section{Perencanaan Tindakan}

Dalam tahap perencanaan tindakan ini hal-hal pokok yang perlu dipersiapkan sebelum pelaksanaan tindakan untuk siklus satu dengan langkah penerapkan "Problem Based-Learning” yaitu:

1) Penentuan pelaku tindakan dan observer: Pelaku tindakan dalam penelitian tindakan kelas ini adalah guru sebangai peneliti sekaligus sebagai observer terhadap pelaksanaan pembelajaran yang dilakukan.

2) Membuat rencana pelaksanaan pembelajaran: Dalam membuat rencana pelaksanan pembelajaran guru harus menyusun kegiatan yang akan dilakukan pada masing-masing kegiatan pembelajaran mulai dari kegiatan awal, kegiatan inti dan kegiatan akhir. yang akan dilaksanakan dalam proses belajar mengajar di dalam kelas, untuk mencapai tujuan yang diinginkan. Menyiapkan soal tes hasil belajar dan pedoman penskorannya Lembar soal tes hasil belajar dan pedoman pensekorannya disiapkan oleh guru (peneliti) berdasarkan kisi-kisi yang ingin dicapai di dalam kegiatan belajar mengajar. Adapun soal tes hasil belajar dan pedoman pensekorannya terlampir pada lampiran.

3) Mendisain alat evaluasi dan merencanakan analisis hasil tes

Dalam menilai sejauh mana kemampuan peserta didikmenerima materi pelajaran maka guru merancang indikator atau deskriptor penilaian untuk guru dan peserta didik yang terdiri dari beberapa item penilaian tiap indikator.

a) Setiap indikator prilaku peserta didik pada penelitian ini penskorannya mengikuti aturan sebagai berikut.

(1) Skor 4 jika $\geq 75 \%$ peserta didikmelakukan deskriptor yang diamati.

(2) Skor 3 jika $\geq 50-74 \%$ peserta didikmelakukan deskriptor yang diamati.

(3) Skor 2 jika $\geq 25-49 \%$ peserta didikmelakukan deskriptor yang diamati.

(4) Skor 1 jika $<25 \%$ peserta didikpeserta didikmelakukan deskriptor yang diamati.

b) Setiap indikator prilaku guru pada penelitian ini penskorannya mengikuti aturan sebagai berikut.

1) Skor 4 diberikan jika 3 deskriptor yang diamati nampak.

2) Skor 3 diberikan jika 2 deskriptor yang diamati nampak 
3) Skor 2 diberikan jika 1 deskriptor yang diamati nampak

4) Skor 1 diberikan jika tidak ada deskriptor yang diamati nampak.

\section{Pelaksanaan Tindakan}

Pelaksanan siklus 1 dilaksanakan dalam satu kali pertemuan dengan alokasi waktu 3x45 menit.

\section{Observasi Belajar Mengajar Pada Siklus I}

Observasi dilakukan oleh observer, dalam hal ini yang berperan sebangai observer adalah guru kelas V SD Negeri 5 Banyumulek. Adapun yang diobservasi adalah aktivitas guru dan siswa. Data aktivitas guru dan peserta didikdidapatkan sebagai berikut:

\section{Hasil Observasi Aktivitas Guru Pada Siklus 1}

Berdasarkan observasi yang dilakukan pada aktivitas guru menunjukkan bahwa kegiatan guru dalam mempersiapkan rencana pembelajaran sudah memenuhi kriteria yang ditetapkan / dilaksanakan yakni minimal tergolong baik. Adapun persentasi ketercapaian pada siklus I adalah 80\%, sedangkan yang diharapkan dapat dicapai adalah guru mampu melaksanakan semua indikator yang telah disusun atau ditetapkan.

\section{Hasil Aktivitas Peserta didik Pada Siklus 1}

Berdasarkan analisis hasil observasi aktivitas peserta didik dari tiap indikator yang ditetapkan ada beberapa yang belum dilakukan peserta didik (dimunculkan), ini menujukkan bahwa aktivitas belajar peserta didik dalam proses pembelajaran tergolong cukup baik. Adapun persentasi ketercapaian pada siklus 1 adalah 53\%. Dapat dilihat pada lampiran.

\section{Hasil Evaluasi Peserta didik Siklus 1}

Alat ukur yang digunakan adalah dengan rumus hasil peserta didik secara individual, yaitu:

$$
\mathrm{NA}=\frac{S A}{S m i} \times 100 \%
$$

Keterangan :

NA $=$ Nilai Akhir

SA $=$ Skor Aktual

Smi $=$ Skor Maksimal ideal

Untuk mencari persentase ketuntasan peserta didik digunakan rumus:

$$
\mathrm{KK}=\frac{P}{N} \mathrm{X} 100 \%
$$

Keterangan:

$$
\begin{aligned}
& \mathrm{KK}=\text { Ketuntasan Klasikal } \\
& \mathrm{P} \quad=\text { Jumlah peserta didik yang } \\
& \text { memperoleh nilai } \geq 65 \\
& \mathrm{~N} \quad=\text { Jumlah peserta didik yang } \\
& \text { mengikuti tes. }
\end{aligned}
$$

Setelah melakukan proses pembelajaran, guru melakukan evaluasi untuk melihat sejauh mana peserta didik menyerap materi yang sudah diajarkan di kelas. Soal evaluasi terdiri atas 27 soal uraiaan dengan alokasi waktu $3 \times 45$ menit. Jumlah peserta didik yang mengikuti evaluasi sebanyak 27 orang dan 3 orang peserta didik tidak masuk karena sakit, izin dan alpa. Hasil yang dicapai pada evaluasi siklus 1 adalah skor terendah 30, sedangkan skor tertinggi adalah 100. Persentasi ketuntasan klasikal hasil evaluasi peserta didikpada siklus 1 ini adalah $74 \%$.

Siklus II

\section{Perencanaan tindakan}

Perencanaan tindakan pada siklus II sama dengan siklus sebelumnya, hanya saja ada perubahan tertentu berdasarkan rekomendasi tindakan yang diberikan pada siklus 1. Adapun materi yang diajarkan pada siklus II ini adalah (1) Pengurangan bilangan pecahan, (2) Pengurangan dan Penjumlahan Bilangan Pecahan.

Hal-hal yang perlu dipersiapkan oleh peneliti pada tahap perencanaan adalah sebagai berikut.

1) Membuat skenario pembelajaran siklus II: Skenario pembelajaran yang disusun disesuaikan berdasarkan hasil refleksi siklus 1. 
2) Menyiapkan lembar observasi untuk mencatat aktivitas peserta didikdan guru siklus II: Lembar observasi yang digunakan tetap sama seperti pada siklus I.

3) Menyiapkan lembar kerja peserta didik sebagai alat evaluasi siklus II

a. Pelaksanaan Tindakan

b. Pelaksanaan siklus II pertemuan pertama pada tanggal 27 September 2015, dan pertemuan kedua pada tanggal 28 September 2015. Pada pertemuan pertama, ketika guru sedang menyampaikan yang terdiri dari tiga kali pertemuan. Adapun materi yang diajarkan pada siklus II ini adalah (1) Pengurangan bilangan pecahan, (2) Pengurangan dan Penjumlahan Bilangan Pecahan.

c. Observasi Belajar Mengajar Pada Siklus II

Observasi dilakukan oleh observer yang sama pada siklus 1 rekan guru. Adapun yang diobservasi adalah aktivitas guru dan siswa. Data aktivitas guru dan peserta didikdidapatkan sebagai berikut.

\section{Hasil Observasi Aktivitas Guru Pada Siklus II}

Berdasarkan observasi yang telah dilakukan pada aktivitas guru menujukkan bahwa, guru dalam mempersiapkan rencana pembelajaran sudah memenuhi kriteria yakni kriteria sangat baik. Dengan demikian indikator yang belum tercapai dapat terpenuhi semua sehingga mengalami peningkatan yang sangat baik. Adapun persentasi ketuntasan adalah $100 \%$. Ini merupakan nilai yang sangat maksimal karena semua indikator muncul atau telah dilaksanakan oleh guru dengan sangat baik, walaupun ada beberapa yang dilakukan dengan kurang maksimal. Dengan demikian pada siklus II ini persiapan dan aktivitas yang dilakukan selama proses KBM telah mengalami peningkatan dari siklus I yakni $20 \%$. Adapun hasil observasi aktivitas kegiatan guru ketika proses kegiatan belajar mengajar untuk memperkuat dapat dilihat pada lampiran.

\section{Hasil Data Aktivitas Peserta didik pada Siklus II}

Berdasarkan observasi yang telah dilakukan pada aktivitas peserta didikketika berlansungnya proses pembelajaran menujukkan bahwa aktifitas peserta didiktergolong aktif dengan persentasi ketuntasan adalah 80\%. Pada siklus II ini peserta didikterlihat serius atau tidak mainmain lagi. Pada siklus II ini merupakan peningkatan yang sangat baik karena rata-rata indikator yang tersusun muncul semua atau telah dilaksanakan oleh peserta didikmeskipun ada beberapa yang tidak dilakukan secara maksimal. Pada siklus II ini telah mengalami peningkatan dari hasil siklus 1 sebesar $27 \%$.

Dari hasil observasi aktivitas peserta didikjuga terlihat pada kesiapan proses pembelajaran sudah nampak lebih baik, hal ini terlihat pada sebagian besar peserta didik tidak lagi ragu-ragu dalam menanggapi ataupun bertanya terkait materi ajar yang mereka pelajari, serta kegiatan akhir yang sempat tak terlaksana pada siklus sebelumnya guru pada siklus II ini telah mampu menggunakan waktu pembelajaran sesuai dengan rencana pembelajaran. Adapun tabel hasil observasi aktivitas peserta didikuntuk memperkuat dapat dilihat pada lampiran.

\section{Hasil Evaluasi Peserta didik Siklus II}

Alat ukur yang digunakan adalah dengan rumus hasil peserta didiksecara individual, yaitu:

$$
\mathrm{NA}=\frac{S A}{S m i} \times 100 \%
$$

Keterangan :

NA $=$ Nilai Akhir

SA $=$ Skor Aktual

Smi $=$ Skor Maksimal ideal 
Untuk mencari persentasi ketuntasan peserta didikdigunakan rumus:

$$
\begin{aligned}
& \text { KK }=\frac{P}{N} \text { X } 100 \% \\
& \text { Keterangan: } \\
& \text { KK = Ketuntasa Klasikal } \\
& \mathrm{P} \quad=\text { Jumlah peserta didikyang } \\
& \text { memperoleh nilai } \geq 65 \\
& \mathrm{~N} \quad=\text { Jumlah peserta didikyang } \\
& \text { mengikuti tes. }
\end{aligned}
$$

Setelah melakukan

proses pembelajaran, guru melakukan evaluasi untuk melihat sejauh mana peserta didik menyerap materi yang sudah diajarkan di kelas. Soal evaluasi terdiri atas 26 soal uraiaan dengan alokasi waktu $3 \times 45$ menit. Jumlah peserta didik yang mengikuti evaluasi sebanyak 29 orang dan 1 orang peserta didik tidak masuk karena sakit. Hasil yang dicapai pada evaluasi siklus II adalah skor terendah 50, sedangkan skor tertinggi adalah 100. Persentasi ketuntasan klasikal hasil evaluasi peserta didikpada siklus II ini adalah $86 \%$.

\section{Pembahasan}

Dalam penelitian tindakan kelas ini, guru menerapkan model Problem BasedLearning untuk meningkatkan prestasi belajar matematika peserta didik pada materi pokok pengerjaan hitung bilangan pecahan. Kegitan penelitian ini dilaksanakan dalam 2 siklus yang masing-masing siklus terdiri dari satu kali pertemuan diperoleh persentase ketuntasan pada siklus 1 adalah 53\% tergolong cukup aktif. Sedangkan berdasarkan lembar observasi aktvitas guru diperoleh persentasi ketuntasan pada siklus 1 adalah $80 \%$ tergolong baik, selain itu juga diperoleh persentasi ketuntasan belajar peserta didik pada siklus 1 adalah $74 \%$ tergolong baik, maka dengan demikian ketuntasan belajar peserta didiktelah tercapai pada siklus1 ini. Namun, melihat masih adanya kekurangan-kekurangan pada siklus 1 dan untuk memperbaiki proses pembelajaran dalam upaya meningkatkan aktivitas dan prestasi belajar peserta didikmaka kegiatan dilanjutkan pada siklus II. Pelaksanaan pembelajaran siklus II dilaksanakan dengan melakukan perbaikan-perbaikan pada kekurangan pada siklus I. Perbaikan dilakukan diantaranya dengan lebih memotivasi peserta didik dalam pembelajaran, memaksimalkan kerjasama kelompok dengan memberi informasi kepada peserta didik untuk selalu serius dalam diskusi, dan membimbing peserta didik didalam membuat kesimpulan materi pengerjaan hitung bilangan pecahan.

Hasil pembelajaran pada siklus II berdasarkan lembar observasi aktivitas siswa, diperolehan persentasi ketuntasan pada siklus II adalah $80 \%$ tergolong aktif. Sedangkan berdasarkan lembar observasi aktvitas guru diperoleh persentasi ketuntasan pada siklus II adalah $100 \%$ tergolong sangat baik, Selain itu juga diperoleh persentasi ketuntasan belajar peserta didik pada siklus II adalah $86 \%$ tergolong sangat baik.

\section{KESIMPULAN}

Dapat disimpulkan bahwa data aktivitas guru dan peserta didik diambil menggunakan lembar observasi, sedangkan data prestasi belajar peserta didik diperoleh melalui tes yang diberikan pada tiap akhir siklus. Berdasarkan hasil penelitian yang telah dilakukan terhadap aktivitas peserta didik dan guru pada siklus I dan II menujukkan bahwa, persentasi ketercapaian peserta didik pada siklus I adalah 53\%. Pada siklus II persentasi ketercapaian peserta didik adalah $80 \%$, sedangkan dari hasil observasi aktivitas terhadap guru pada siklus I dan siklus II menujukkan bahwa, persentasi ketercapaian guru pada siklus I adalah $80 \%$, dan pada siklus II persentasi ketercapaian guru adalah $100 \%$, dan hasil evaluasi peserta didik pada siklus I diperoleh persentasi ketuntasan belajar peserta didik sebesar $74 \%$, sedangkan pada siklus II diperoleh persentasi ketuntasan belajar peserta didiksebesar 86\%. Sehingga terjadi peningkatan prestasi belajar peserta didik dari siklus I ke siklus II sebesar $12 \%$. Ini menandakan bahwa penerapan model 
Problem

Based-Learning

dapat meningkatkan aktivitas dan prestasi belajar peserta didikpada materi pokok pengerjaan hitung bilangan pecahan peserta didik kelas V SD Negeri 5 Banyumulek Kabupaten Lombok Barat Tahun Pelajaran 2019/2020.

\section{DAFTAR PUSTAKA}

Aren, R. I. (2008). Learning to teach $\left(7^{\text {th }}\right.$ ed). New York: McGraw Hill Companies.

Aqib, Z. (2006). Penelitian tindakan kelas. Bandung: Yarma Widya.

Barrows. (1982). Problem based-learning an approach of medical education. New York: Springer Publishing.

Cheong, F. (2008). Using a problem based learning approach a teach an intelligent system course. Jurnal of Information Technologi Education.

Djamarah, S.B. (1994). Prestasi Belajar dan Kompetensi Guru. Surabaya: Usaha Nasional.

Duch, B. J., Groh, S. E., \& Allen, D. E. (2000). The power of problem based learning: a practical "how to" for teaching undergraduate courses in any discipline. Sterling: Stylus Publishing LLC.

Gintings, A. (2008). Esensi praktis belajar dan pembelajaran. Bandung: Humanior.

Hamalik, O. (2001). Perencanaan pengajaran. Jakarta: Rineka Cipta.

Irzani. (2010). Pembelajaran matematika panduan praktis untuk pengajaran SD dan MI. Yogyakarta: Mandiri Graffindo Press.

Irzani. (2009). Strategi belajar mengajar matematika. Yogyakarta: Media Grafindo Press.

Kusmiati. (2006). Model-model penelitian. Jakarta: Gramedia.

Leven, B. B. (2001). Energizing teacher education and profesional development with problem based learning. Alexandria: Association for Supervision and Curricculum Development (ASCD).

Mudjiono. (2006). Belajar dan pembelajaran. Jakarta: PT Rineka Cipta.

Munadi, Y. (2008). Media pembelajaran. Jakarta Gaung: Press Persada.

Nurkencana, W. (1983). Evaluasi hasil belajar. Surabaya: Usaha Nasional.

Nur, A. (2004). Matematika klas IV sekolah dasar. Karangano: Cempaka Putih.

Pepper, C. (2009). Problem based learning in science. Jurnal: Issues in Educational Research. Volume 9 (2).

Ruseffendi. (2009). Strategi belajar mengajar matematika. Yogyakarta: Media Grafindo Press

Sanjaya, W. (2008). Strategi pembelajaran berorientasi standar proses pendidikan. Jakarta: Fajar Interpratama.

Tan, Oon-Seng. (2009). Problem based learning and creativity. Singapore: Cengage Learning Asia Pte Ltd. 